\title{
PEMAKAIAN AKRONIM DI LINGKUNGAN PEMERINTAH KOTA SURABAYA
}

\author{
Regina Pramesti Ragam \\ Universitas Airlangga Surabaya \\ email: regina.pramesti.ragam-2019@pasca.unair.ac.id
}

\begin{abstract}
(Title: Use of Acronyms in the Surabaya City Government). This study examines the acronyms used by the Surabaya City Government. There are several objectives to be achieved in this research. The first is to describe the reasons why acronyms are widely used in the Surabaya City Government environment to describe the effect of using acronyms for smooth communication in the Surabaya City Government environment. The second is to describe the patterns of acronym formation in the Surabaya City Government. The third describes the existing acronyms whether they are in accordance with the Indonesian Phonotactic rules. The data in this study were collected by using a questionnaire and the observation method. The results show that there are two reasons why the Surabaya City Government uses a lot of acronyms. There are two reasons that are expected from the use of acronyms, but in fact the use of acronyms has an effect. In addition, the acronym found in the Surabaya City Government Environment has three patterns of formation. In connection with the formation of a word acronym pattern, it generally consists of a series of sounds with the status of an Indonesian word. Therefore, acronyms should be in harmony with the Indonesian Phonotactic rules. The phonotactics used in this study include the distribution of vowels, distribution of consonants and clusters.
\end{abstract}

Keywords: acronyms, Surabaya City Government, phonotactics, structuring patterns.

\section{PENDAHULUAN}

Kosa kata bahasa Indonesia sudah banyak mengalami perkembangan, sehingga membuat wujud kata tersebut menjadi banyak pergantian atau variasi. Variasi dalam perubahan bentuk kosa kata bahasa Indonesia ini salah satunya ialah adanya abreviasi. Abreviasi merupakan proses pemendekan kata melalui pemenggalan suatu kata atau leksem yang dikombinasi sehingga menjadi sebuah kata yang baru. Menurut Kridalaksana (2007: 159), menyebutkan bahwa abreviasi merupakan suatu bentuk pemendekan satu kata atau beberapa kata dimana menjadi sebuah bentuk susunan kata baru yang pendek. Hasil yang ditunjukan dari bentuk pemendekan kata pada abreviasi disebut dengan penyingkatan. Dalam abreviasi suatu kata didalamnya terdapat bermacam-macam klasifikasi pemendekan kata misalnya seperti singkatan, akronim, dan pemenggalan.

Akronim adalah kata yang diciptakan dari huruf awal nama kata, nama judul, atau frasa karena kata ciptaan itu sebenarnya dilafalkan seperti kata baru (Bauer 1988, hlm. 39). Pemendekan dalam suatu kata melalui akronim merupakan hal yang tidak baru lagi bahkan disebagian besar masyarakat sudah sangat lazim digunakan,misalnya pada forum resmi atau formal seperti pada lingkup pemerintah. 
Faktanya menunjukan bahwa akronim yang digunakan pada lingkungan pemerintah akan membawa manfaat serta dampak bagi aktivitas pekerjaan di Pemerintah Kota Surabaya dalam hal berkomunikasi. Akronim yang digunakan dalam berkomunikasi pada lingkungan kerja ini sedikit banyak akan mempengaruhi kinerja pegawai pemerintah. Faktanya akronim yang digunakan pada lingkungan pemerintah akan membawa manfaat serta dampak bagi aktivitas pekerjaan di Pemerintah Kota Surabaya dalam hal berkomunikasi. Akronim yang digunakan dalam berkomunikasi pada lingkungan kerja ini sedikit banyak akan mempengaruhi kinerja pegawai pemerintah.

Fonotaktik Bahasa Indonesia memiliki kaidah dalam bunyi yang terangkai dari suatu kata,karena akronim merupakan singkatan yang dilafalkan seperti kata. Maka dari itu alangkah baiknya apabila dibuat sesuai dengan kaidah tersebut dengan baik dan benar agar, tidak menyalahi kaidah struktur bahasa Indonesia. Setelah, kata tersebut dibentuk menjadi akronim akankah kata tersebut masih selaras dengan kaidah bahasa Indonesia yang baik dan benar.

\section{METODE}

Penelitian ini merupakan penelitian kualitatif dan menggunakan dua metode. Metode pertama yaitu menggunakan teknik wawancara secara tertulis, menggunakan kuesioner untuk mengumpulkan data jenis pertama dan kedua yaitu tentang alasan dan efek penggunaan akronim pada Lingkungan Pemerintah Kota Surabaya. Kuesioner yang dibagikan berisi pertanyaan-pertanyaan yang relevan untuk mendapatkan data-data yang mencakup permasalahan yang diangkat dan berpedoman pada temuan selama pengamatan di lapangan. Sasaran dari kuesioner yang dibagikan ialah pegawai atau staff di Lingkungan Pemerintah Kota Surabaya.
Metode kedua ini yaitu menyimak berbagai dokumen,arsip dan sumber-sumber tulisan yang terdapat pada lingkungan pemerintah. Metode simak merupakan metode yang dilakukan dengan penyimakan, metode ini disejajarkan dengan metode observasi.

\section{PEMBAHASAN}

\section{Pemakaian Akronim di Lingkungan \\ Pemerintah Kota Surabaya}

Penggunaan akronim di lingkungan Pemerintah Kota Surabaya digunakan untuk menyederhanakan sebuah kata yang panjang dan terkadang susah diingat agar menjadi bentuk kata yang singkat,padat dan jelas. Contohnya dalam penulisan surat-surat resmi terdapat akronim seperti (1) Penerapan review-review Renstra.

Akronim pada data (1) digunakan pada surat Keputusan Kepala Dinas Pekerjaan Umum Bina Marga dan kota Surabaya Nomor: 500/632/436.7.3/2017. Akronim Renstra merupakan kepanjangan dari Rencana Strategis yang disingkat menjadi satu bentuk kata sederhana sehingga mempermudah komunikasi dalam peristilahan kosa kata di pekerjaan. Akronim renstra ini ditemukan pada berkas pemerintah, bahkan dalam sampul depan berkas itu juga menggunakan akronim pada data (1) sebagai bentuk perwujudan akronim kata dari rencana strategis.

\section{Pemahaman Pegawai mengenai Akronim di lingkungan Pemerintah Kota Surabaya}

Akronim yang ada pada Pemerintah Kota Surabaya ini sudah banyak digunakan dalam pekerjaan sehari-hari. Pegawai pekerjaan bidang pemerintah ini tidak lepas dari adanya akronim kata, seperti data-data yang sudah dipaparkan di atas. Dalam kesehariannya pegawai di kantor pemerintah ini sudah akrab mengenai adanya akronim pada bidang mereka, 
tetapi pegawai pemerintah ini tidak sepenuhnya mengetahui tentang akronim yang ada di Lingkungan Pemerintah Kota Surabaya. Kenyataannya, para pegawai ini belum sepenuhnya hafal terkait dengan kepanjangan akronim-akronim yang ada.

Akronim merupakan singkatan kata yang diperlakukan dan dibaca seperti kata pada umumnya. Kendala penggunaan akronim pada lingkungan Pemerintah Kota Surabaya ini disebabkan oleh dua faktor.Faktor tersebut diantaranya yaitu, pegawai pemerintah yang berasal dari kalangan pendidikan yang berbeda. Dalam artian, para pekerja pemerintahan ini berasal dari berbagai background pendidikan yang berbeda. Sehingga, pengetahuan mereka tentang pemahaman sebuah kata akan berbeda pula. Jadi, terkait dengan akronim yang muncul pada lingkungan Pemerintah Kota Surabaya tersebut akronim ini terbentuk tanpa adanya sebuah aturan yang jelas. Faktor kedua berasal dari masing-masing individu soal tingkat pengetahuan dan daya ingat, karena pada dasarnya manusia memiliki keterbatasan ingatan soal kata-kata baru atau asing. Sehingga, akronim kata ini kurang dipahami dengan baik.

Akronim di bentuk dengan harapan untuk menggunakan persitilahan kata, agar menjadi lebih baku dan formal terhadap tata naskah serta kinerja Pemerintah Kota Surabaya. Sehingga, penulisannnya menjadi lebih ringkas untuk itu dibuatlah cara agar kosa kata tersebut menjadi lebih gampang diingat yaitu dengan cara menyederhanakan konsep kata melalui akronim atau singkatan.

Banyak nya akromin yang tidak dipahami oleh pegawai pemerintahan tersebut karena ada dua faktor. Faktor yang pertama berasal dari masing-masing individu soal tingkat pengetahuan dan daya ingat, karena pada dasarnya manusia memiliki keterbatasan ingatan soal kata-kata baru atau asing.

Faktor kedua berasal dari pemerintah untuk menggunakan persitilahan kata, agar menjadi lebih baku dan formal terhadap tata naskah serta kinerja Pemerintah Kota Surabaya. Sehingga, penulisannnya menjadi lebih ringkas. Sehingga, dibuatlah cara agar kosa kata tersebut menjadi lebih gampang diingat yaitu dengan cara menyederhanakan konsep kata melalui akronim atau singkatan.

- Agar komunikasi berjalan secara efektif

- Agar komunikasi lebih jelas,singkat dan...

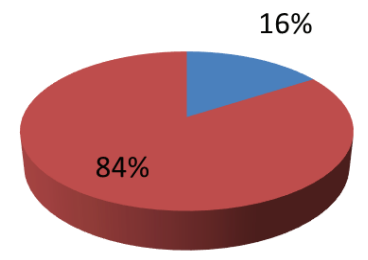

Kendala komunikasi yang terjadi ini disebabkan pemakaian akronim kurang tepat kepanjangannya sehingga muncul makna yang ganda, akronim kata yang terbentuk terdengar seperti bahasa asing, serta akronim yang ada terlalu banyak jumlahnya dan susah untuk diingat.

\section{Efek Akronim Bagi Kelancaran}

Komunikasi di Pemerintah Kota Surabaya

Pegawai pemerintah ini memiliki beraneka ragam kosa kata yang berbeda. Pada setiap bagian dinas dan memungkinkan bahwa perbedaan presepsi atau pengetahuan tiap manusia juga berbeda satu dengan yang lain. Misalnya, pada Dinas Kesehatan mengenal dengan adanya akronim kata pada tabel 4.1 di atas.

Pada data (6) dan (7) di bawah ini merupakan bukti bahwa akronim-akronim tersebut menimbulkan efek berupa kerancuan penggunaan dan penulisan yang ada di lingkungan 
pemerintah. Berikut ini pemaparannya.

Data (6) di bawah ini terdapat akronim yang merupakan kepanjangan dari puskesmas pembantu, dari data tersebut kata puskesmas merupakan akronim Pusat Kesehatan Masyarakat yang memang sudah di bentuk menjadi akronim. Kemudian, data (6) menunjukan bahwa akronim kata yang sudah terbentuk dihadirkan kembali dalam bentuk akronim pula yaitu pustu. Sehingga, akronim kata puskesmas di akronimkan kembali menjadi pustu karena mendapatkan tambahan kata pembantu.

Pada dasarnya orang sudah banyak yang memahami tentang kepanjangan dari puskesmas, sama halnya dengan pegawai Pemerintah Kota Surabaya juga dapat di katakan bahwa akronim ini tidak asing lagi. Tetapi, apabila ada kata seperti data (6) ini, maka timbul peristilahan kata yang asing bahkan seperti aneh. Kata puskesmas yang pada dasarnya memang akronim lalu di gabungkan lagi dengan katakata lain sehingga menjadi akronim dalam akronim. Hal ini yang dimaksud akronim dalam akronim. Berikut datanya seperti di bawah ini.

(6) pustu

(7) perkin

Dinas Pekerjaan Umum terdapat sebuah akronim data (7) yang merupakan kepanjangan dari Perjanjian kinerja. Akronim perkin ini dibentuk untuk mempermudah penulisan kata perjanjian dan kinerja, dengan adanya akronim pada data (7) diharapkan dapat mempermudah proses pengingatan kata. Sehingga, akronim ini dapat memberikan efek kemudahan dan kelancaran untuk berkomunikasi di lingkungan Pemerintah Kota Surabaya. Tetapi realitanya adanya akronim pada data (7) ini juga ditemukan dalam wujud akronim atau singkatan kata lain yaitu $P K$. Akronim tersebut merupakan kepanjangan dari Perjanjian Kinerja. Data (7) merupakan bukti bahwa kurang konsistennya pembentukan akronim yang ada se- hingga dapat memiliki efek berupa multitafsir dan tidak konsisiten dalam penulisan dan penggunaannya.

Pada dasarnya setiap hal pasti memiliki fungsi dan tujuan, sama halnya dengan akronim yang ada memiliki tujuan dan fungsi sebagai berikut :

1. Untuk menyederhanakan konsep kata yang panjang hingga menjadi ringkas.

2. Untuk menyingkat kata-kata yang terlalu panjang agar menjadi praktis sehingga mudah diingat.

3. Sebagai perwujudan simbol atau kode bahwa dalam sebuah instansi memiliki kosa kata yang jarang dikenali oleh orang luar atau awam.

4. Menghemat pengucapan dalam berkomunikasi baik lisan maupun tulisan.

\section{SIMPULAN}

Akronim yang terdapat pada lingkungan Pemerintah Kota Surabaya ini digunakan berdasarkan kepentingan kelancaran kerja agar menjadi lebih ringkas dan membuat peristilahan kata pada menjadi efektif dan mudah diingat. Selain itu akronim-akronim yang ada pada ini digunakan agar kosa kata pada bidang pemerintah menjadi lebih jelas,singkat,mudah diingat. Hasil kuesioner juga menunjukan bahwa pegawai Pemerintah Kota Surabaya yang menggunakan akronim karena mempermudah untuk menjalankan tugas sehari-hari yang sesuai dengan bidang kerjanya agar mudah diingat.Pemakaian akronim pada lingkungan ini juga terkait dengan adanya pemahaman pegawai Pemerintah Kota Surabaya dengan akronim yang terbentuk.

Munculnya akronim-akronim pada lingkungan kerja mereka yang seharusnya mempermudah untuk menjalankan tugas sehari-hari. Tetapi, ternyata malahan menjadi kendala sehingga mengganggu komunikasi 
dalam pekerjaan, serta menimbulkan efek. Efek dari penggunaan akronim yang pertama ialah tersendatnya proses berkomunikasi antar pegawai yang membuat misscomunication, sehingga membuat maksud dan tujuan dari pembicaraan kurang tersampaikan dengan baik. Pada dasarnya komunikasi memegang peranan yang penting dalam menjalankan pekerjaan sehari-hari,maka dari itu pegawai Pemerintah Kota Surabaya seharusnya dapat mengerti mengenai akronim-akronim yang ada di lingkungan kerja mereka demi terwujudnya kelancaran kerja. Efek yang kedua adanya akronim dalam lingkungan Pemerintah Kota Surabaya membuat pegawai pemerintah menjadi bingung dan kesulitan menggunakan akronim yang ada dikarenakan kurang konsistennya akronim yang digunakan pada teks atau dokumen pemerintah. Akronim yang terdapat dalam Pemerintah Kota Surabaya ini tidak dimengerti karena beberapa faktor. Faktor tersebut diantaranya adalah: 1). Banyaknya kosa kata atau peristilahan yang ada pada lingkungan pemerintah, 2).Kemampuan setiap individu pegawai pemerintah berbeda, 3).Kurangnya konsistensi mengenai pembuatan akronim dan penggunaanya, 4).Terdiri atas banyak dinas atau bidang pemerintah sehingga memungkinkan semakin banyak akronim yang di bentuk menjadi kurang tepat.

\section{UCAPAN TERIMA KASIH}

Alhamduillah terima kasih penulis panjatkan puji dan syukur kepada Tuhan YME dan orang-orang yang membantu penulis dalam keadaan apapun serta, Secara khusus peneliti mengucapkan terima kasih kepada Prof. Dr. Anwar Efendi, M.Si. dan Ibu Dr. Yeni Artanti, M. Hum yang telah memberikan masukan dan pendampingan dalam penulisan artikel ini.

\section{DAFTAR PUSTAKA}

Acrti Rahayu,2013.Analisis Makna Dalam Kalimat Bahasa Jepang. Skrpsi: UPI.

Alwi, H., Lapoliwa, H., dan Darmowidjojo, S. (2003). Tata bahasa baku bahasa

Indonesia(Edisi Ketiga). Jakarta: Balai Pustaka.

Beldi,Ludgerdius.2016. Pembentukan Singkatan dan Akronim Dalam Forum Kaskus. Skripsi:Uny.Tersedia di:

Chabibah,Shelya.2018. Perkembangan Kosakata Dan Fonotaktik Pada Buku Ajar Bipa Tingkat A1-C2 Terbitan Kemendikbud.Jurnal:Unesa.Tersedia di: http:// jurnalmahasiswa.unesa.ac.id/index.php/ bapala/article/view/25793/23638 (diakses 30-Maret-2018, pukul: 21:17).

Chaer, Abdul. 2009. Fonologi Bahasa Indonesia. Jakarta: Rineka Cipta.

Handayani, Natalia Veni .2013.Analisis Kosakata Slang Pada Komunitas Mantan Pengguna Narkoba Di Rumah Sakit Grhasia Sleman. . Skripsi:UNY. Tersedia di:

http://eprints.uny.ac.id/22244/1/Natalia $\% 20$ Veni\%20Handaya ni\%2006210141002. pdf (diakses 22-Oktober-2018 pada pukul: 09:27).

http://repository.unair.ac.id/44424/2/Binder1. pdf (diakses 15- Maret- 2019 pada pukul 12:06). http://repository.upi.edu/8748/4/s jep_0807395_chapter3.pdf (diakses 11-April- 2018).

http://www.academia.edu/4395125/Kaidah_ Fonotaktik_Akronim, diakses14 November 2018 pada pukul: 11:51.

http://www.linguistikindonesia.org/ images/files/08.\%20Pergeseran $\% 20$ Pembentukan\%20Kata\%20-\%20M.\%20 Zaim\%20(173-192)\%20-\%20040416. pdf ,diakses 27-maret-2018 pada pukul: 
$12: 38$.

Handayani. 2009. Linguistik Umum. Jakarta: Rineka Cipta.

Jauhari,Edy.1997.Prisnsip Ekonomi Dalam Bahasa Indonesia. Thesis: Unair. Dapat di akses :

Kridalaksana, H. (1990). Kelas kata dalam bahasa Indonesia. Jakarta: PT Gramedia.

Kridalaksana, H. 2008. Kamus Linguistik (edisi keempat). Jakarta: PT. Gramedia

Kridalaksana, H. 2010. Pembentukan Kata dalam Bahasa Indonesia. Jakarta: PT. Gramedia.

Lieber, R. (2009). Introducing morphology. Cambridge: Cambridge University Press.

M.S., Mahsun. 2007. Metode Penelitian Bahasa: Tahapan Strategi, Metode, dan

Mahsun. 2005. Metode penelitian bahasa. Jakarta: Raja Grafindo Persada.

Nugraha, Krida.1996. Kaidah bahasa Indonesia: Kata-Kata, Kalimat, dan Akronim Baku. Solo: CV. Aneka.

Nurjaya,IGede.2015.Struktur Fonotaktik Akronim dalam Koran :Menuju kaidah pembentukan akronim yang mudah dilafalkan. Indonesia. Departemen Koperasi. Inspektorat Jenderal.
Pusat Bahasa. 2004. Pedoman umum ejaan bahasa Indonesia yang disempurnakan. Jakarta: Pusat Bahasa, Departemen Pendidikan Nasional.

Pusat Bahasa. 2007. Pedoman umum pembentukan istilah. Jakarta: Pusat Bahasa, Departemen Pendidikan Nasional.

Pusat Pembinaan dan Pengembangan Bahasa. 2008. Kamus Besar Bahasa Indonesia. Jakarta: Departemen Pendidikan Nasional.

Pustaka Utama.

Zaim,M .2015. Pergeseran Sistem Pembentukan Kata Bahasa Indonesia: Kajian Akronim, Blending, dan Kliping.Jurnal: UNP. Tersedia di: https://repository.usd.ac. id/6479/2/114114029_full.pdf (diakses pada 27-maret-2018 pada pukul: 13.37).

Susilawati. 2010. "Kaidah Fonotaktik Gugus Konsonan Kata-Kata Bahasa Indonesia yang Bersuku Dua". Skripsi. Surakarta. Universitas Muhammadiyah Surakarta.

Tarigan, Karana Jaya. 2007. "Fonotaktik Bahasa Kara Internet”. Skripsi. Http://repository.usu.ac.id/bitstream/123456789/ cover.pdf. Diakses pada 07 Juni 2020. 